\title{
METHODS FOR STUDYING MINERAL AND TRACE ELEMENT ABSORPTION IN HUMANS USING STABLE ISOTOPES*
}

\author{
B. SANDSTRÖM ${ }^{1}$, S. FAIRWEATHER-TAIT ${ }^{2}$, R. HURRELL ${ }^{3}$ \\ AND W. VAN DOKKUM ${ }^{4}$
}

${ }^{1}$ Research Department of Human Nutrition, Royal Veterinary and Agricultural
University, Rolighedsvej 25, DK-1958 Frederiksberg C, Denmark
${ }^{2}$ AFRC Institute of Food Research, Norwich Laboratory, Norwich Research Park,
Colney, Norwich NR4 7UA, England
${ }^{3}$ Nestec Ltd, Nestlé Research Centre, CH-1000 Lausanne 26, Switzerland
${ }^{4}$ TNO Nutrition and Food Research, PO Box 360, NL-3700 AJ Zeist, The Netherlands

\section{CONTENTS}

INTRODUCTION .

CONSIDERATIONS IN USING STABLE ISOTOPES . . . . . . 73

RADIOACTIVE $v$. STABLE ISOTOPES . . . . . . . . . . . . 73

AVAILABLE STABLE ISOTOPES . . . . . . . . . . . . . . . 73

Cost. . . . . . . . . . . . . . . . . . 73

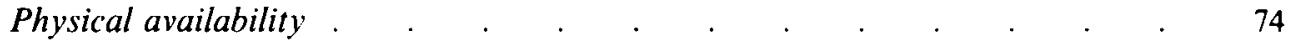

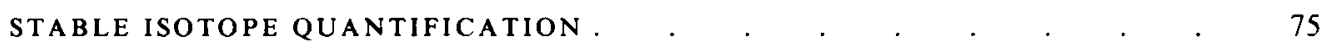

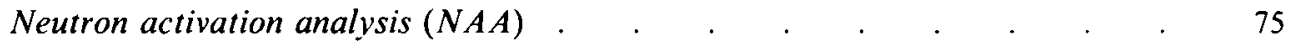

Thermal ionization mass spectrometry (TIMS). . . . . . . . . . . . 76

Fast atom bombardment mass spectrometry (FABMS) . . . . . . . 76

Inductively coupled mass spectrometry (ICPMS) . . . . . . . . . . . . $\quad$. 77

Electron impact mass spectrometry (EIMS) and gas chromatography mass

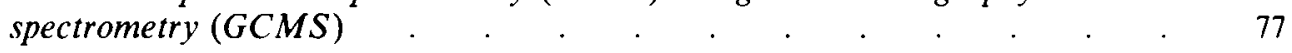

PREPARATION AND ADMINISTRATION OF STABLE ISOTOPES . . . 77

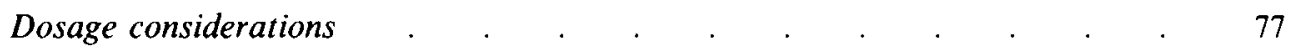

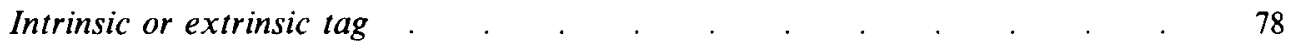

GENERAL PRINCIPLES OF ABSORPTION STUDIES . . . . . . $\quad 82$

STUDY TECHNIQUES. . . . . . . . . . . . . . . . . . 82

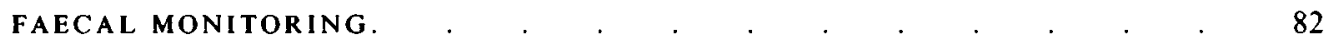

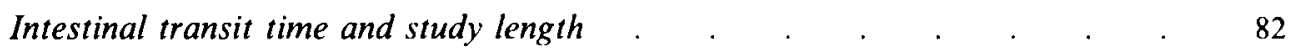

Endogenously excreted elements . . . . . . . . . . . . . . . . . 83

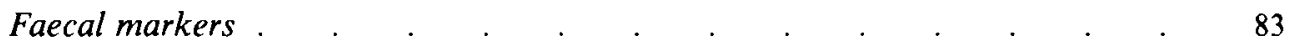

Application of the faecal monitoring technique in adults for individual elements 84

* A joint paper produced within FLAIR Concerted Action No. 10: 'The measurements of micronutrient absorption and status'. 
Zinc, copper and iron. . . . . . . . . . . . . . . . . . . . 84

Magnesium. . . . . . . . . . . . . . . . . . 84

Selenium . . . . . . . . . . . . . . . . . . . . . 84

Infant studies .

TISSUE RETENTION .

SIMULTANEOUS ORAL AND INTRAVENOUS ADMINISTRATION . 86

Calcium . . . . . . . . . . . . . . . . . . . 86

Zinc . . . . . . . . . . . . . . . . . . . . 87

Magnesium. . . . . . . . . . . . . . . . . . . . 88

Selenium . . . . . . . . . . . . . . . . . . . . . 88

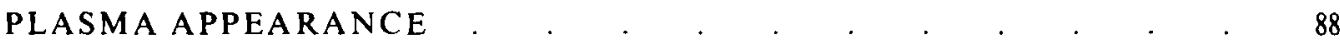

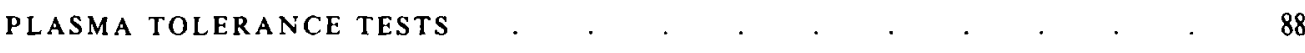

Zinc. . . . . . . . . . . . . . . . . 89

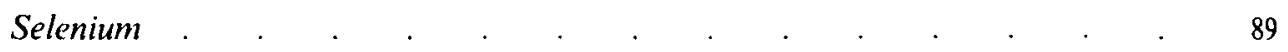

DECONVOLUTION . . . . . . . . . . . . . . . . . 89

USE OF STABLE ISOTOPES FOR STUDIES OF MINERAL AND TRACE

ELEMENT METABOLISM . . . . . . . . . . .

CONCLUSIONS AND RECOMMENDATIONS . . . . . . . . . . 90

REFERENCES . . . . . . . . . . . . . . . . . . . 91

\section{INTRODUCTION}

The adequacy of a dietary intake of minerals and trace elements cannot be evaluated from the total content of the elements. Physiological and dietary factors affect the degree of intestinal absorption, so that for most elements only a fraction of dietary intake is absorbed and utilized for body functions. Knowledge about the effects of physiological and dietary factors on mineral absorption and utilization in man is still limited to a large extent by the lack of sensitive analytical methods.

Traditionally, mineral absorption has been investigated by the use of the chemical balance technique, namely the difference between intake and faecal content of the element. However, for most minerals and trace elements, especially those with a low fractional absorption and/or a significant intestinal endogenous excretion, the balance technique does not provide meaningful data on absorption. The balance technique is time and labour consuming, and in addition the precision is low due to inherited problems in separating faecal content according to the corresponding dietary period. This latter problem can be partly overcome by longer balance periods with a constant diet, but this introduces the opportunity for adaptive changes in absorption and/or excretion that makes the interpretation of the results difficult. The major disadvantage with the conventional balance technique is, however, that the true absorption from a foodstuff or a diet cannot be determined as there is no way to distinguish in the faecal samples between non-absorbed elements of dietary origin and the same elements excreted endogenously. The use of isotopes to label food minerals and trace elements allows studies of absorption from both single foods and total diets and it also makes possible the systematic study of the many factors that influence absorption.

The purpose of this review is to describe and discuss the advantages and disadvantages of the methods used for studying mineral and trace element absorption in humans with special emphasis on the use of stable isotopes. 


\section{CONSIDERATIONS IN USING STABLE ISOTOPES}

\section{RADIOACTIVE v. STABLE ISOTOPES}

The basic principle for isotope studies is that an added isotope of the element exchanges with or behaves in an identical way to the native element. The added isotopes could either be $\beta$ - or $\gamma$-emitting radioactive isotopes or an enriched naturally occurring isotope. Most elements in their native form are a mixture of isotopes with slightly different masses (Table 1).

Radioisotopes with suitable half-lives can be produced for most elements of nutritional interest. Their main advantages are the ease and precision of the measurements, and the isotope can be added as a true tracer without changing the total element content in the diet. In addition, body retention of the element can be measured directly with $\gamma$-emitting isotopes. Radioisotopes are relatively cheap, but require expensive measurement equipment, including skilful technical assistance, in order to optimize the measurement conditions so that the radiation doses can be kept as low as possible.

The potential hazard of ionizing radiation is the major disadvantage of this method, which excludes its use for groups like children and pregnant women. With a sensitive whole body counter, however, the radiation doses can be kept typically below $1 \mathrm{mSv}$. This corresponds to less than $1 / 3$ of natural background radiation or medical radiation doses obtained by an X-ray examination and is similar to the radiation doses received in an $8 \mathrm{~h}$ overseas flight. Radioisotopes are also less suitable for multielement studies and multiple administrations. Apart from the cumulative radiation dose there are also measurement difficulties due to overlapping energy spectra. Because of these concerns about radioactivity and with the improvement of analytical techniques for stable isotopes the use of stable isotopes as labels is becoming an attractive alternative.

The great advantage with stable isotopes is the safety. In principle, an enriched stable isotope can be used as a tracer for the native element in a similar way to a radioisotope. However, while radioisotopes can be added in virtually carrier free solutions of the element, in order to be accurately measured stable isotopes often have to be added at levels that substantially increase the total element intake. The cost of stable isotopes is generally higher than that of radioisotopes; however, there are no losses due to radioactive decay in collected and stored samples. Whereas radioisotopes can be measured more or less directly in the total body or in biological samples, the analysis of stable isotopes requires pretreatment in order to remove organic matrices and other interfering substances, and the total body retention of stable isotopes cannot be measured by whole body counting.

Thus the main factors to consider when choosing between radioactive and stable isotopes are firstly the ethical aspects, followed by the availability and cost of isotopes and the access to analytical instruments and skills.

\section{AVAILABLE STABLE ISOTOPES}

\section{Cost}

The prices of inorganic stable isotopes vary considerably. They depend on the country of origin, the supply company or organization, the quantity ordered, and the current foreign exchange rates. Stable isotopes are also subject to the law of demand and supply whereby a rise in demand enables the producers and/or suppliers to increase the purchase price. Thus over the last decade the cost of stable isotopes has risen very significantly, particularly for metals of topical interest such as calcium, zinc and iron.

An indication of prices recently quoted (October-December 1992) for isotopes that may 
Table 1. Mineral and trace element isotopes for nutrition research

\begin{tabular}{|c|c|c|c|c|}
\hline \multirow[b]{2}{*}{ Element } & \multicolumn{2}{|c|}{ Radioisotopes } & \multicolumn{2}{|c|}{ Stable isotopes } \\
\hline & Mass no. & Half-life & Mass no. & Atom $\%{ }^{1}$ \\
\hline $\mathrm{Ca}$ & $\begin{array}{l}45 \\
47\end{array}$ & $\begin{array}{l}165 \mathrm{~d} \\
4.53 \mathrm{~d}\end{array}$ & $\begin{array}{l}40 \\
42 \\
43 \\
44 \\
46 \\
48\end{array}$ & $\begin{array}{r}96.941 \\
0.647 \\
0.135 \\
2.086 \\
0.004 \\
0.187\end{array}$ \\
\hline $\mathrm{Cr}$ & 51 & $27 \cdot 8 \mathrm{~d}$ & $\begin{array}{l}50 \\
52 \\
53 \\
54\end{array}$ & $\begin{array}{r}0.250 \\
83.789 \\
9.501 \\
2.365\end{array}$ \\
\hline $\mathrm{Fe}$ & $\begin{array}{l}55 \\
59\end{array}$ & $\begin{array}{r}2.6 y \\
45.1 d\end{array}$ & $\begin{array}{l}54 \\
56 \\
57 \\
58\end{array}$ & $\begin{array}{c}5 \cdot 8 \\
91 \cdot 72 \\
2 \cdot 2 \\
0 \cdot 28\end{array}$ \\
\hline $\mathrm{Cu}$ & 64 & $12 \cdot 9 \mathrm{~h}$ & $\begin{array}{l}63 \\
65\end{array}$ & $\begin{array}{l}69 \cdot 17 \\
30 \cdot 83\end{array}$ \\
\hline $\mathrm{Zn}$ & $\begin{array}{l}65 \\
69 m\end{array}$ & $\begin{array}{r}243.6 \mathrm{~d} \\
13.9 \mathrm{~h}\end{array}$ & $\begin{array}{l}64 \\
66 \\
67 \\
68 \\
70\end{array}$ & $\begin{array}{r}48.6 \\
27.9 \\
4.1 \\
18.8 \\
0.6\end{array}$ \\
\hline $\mathrm{Mg}$ & 28 & $21 \mathrm{~h}$ & $\begin{array}{l}24 \\
25 \\
26\end{array}$ & $\begin{array}{l}78.99 \\
10 \cdot 00 \\
11.01\end{array}$ \\
\hline $\mathrm{Se}$ & 75 & $120 \cdot 4 d$ & $\begin{array}{l}74 \\
76 \\
77 \\
78 \\
80 \\
82\end{array}$ & $\begin{array}{r}0.89 \\
9.36 \\
7 \cdot 63 \\
23 \cdot 78 \\
49 \cdot 61 \\
8.73\end{array}$ \\
\hline $\mathrm{Mn}$ & $\begin{array}{l}52 \\
54\end{array}$ & $\begin{array}{l}5.7 d \\
303 d\end{array}$ & 55 & 100 \\
\hline
\end{tabular}

1 From DeLaeter et al. (1991).

be of use in absorption studies is given in Table 2. The listings indicate the current position of availability and price but both are subject to change without notice, and the cost does not include postage, packing, and order processing charges.

\section{Physical availability}

At present inorganic stable isotopes are only being produced commercially in Eastern Europe, but limited quantities are available as a byproduct in the UK (AEA Technology). Production in the USA (Oak Ridge) stopped over a year ago and orders are being met from existing stocks. In general, isotopes are less expensive when obtained from Russia, but there has been some uncertainty surrounding the delivery of orders over the past few years, although these problems now seem to have been resolved. 
Table 2. Cost of stable isotopes $(1992 / 3)^{1}$

\begin{tabular}{|c|c|c|c|}
\hline Element & Isotope & $\begin{array}{l}\text { Enrichment } \\
\text { (atom \%) }\end{array}$ & $\begin{array}{c}\text { Price } \\
\text { (US\$/mg } \\
\text { of element) }\end{array}$ \\
\hline Magnesium & $\begin{array}{l}25 \\
26\end{array}$ & $\begin{array}{l}73-99 \\
9799\end{array}$ & $\begin{array}{l}7-11 \\
7-9\end{array}$ \\
\hline Calcium & $\begin{array}{l}42 \\
43 \\
44 \\
46 \\
48\end{array}$ & $\begin{array}{r}83-94 \\
5683 \\
96 \quad 98 \\
5 \quad 30 \\
73-97\end{array}$ & $\begin{array}{c}44-98 \\
194-424 \\
10-25 \\
250-3896 \\
152270\end{array}$ \\
\hline Chromium & $\begin{array}{l}50 \\
53 \\
54\end{array}$ & $\begin{array}{l}88-97 \\
95.98 \\
93-96\end{array}$ & $\begin{array}{l}26-67 \\
1329 \\
55-164\end{array}$ \\
\hline Iron & $\begin{array}{l}54 \\
57 \\
58\end{array}$ & $\begin{array}{l}9597 \\
80-97 \\
65-93\end{array}$ & $\begin{array}{c}13-18 \\
17-44 \\
120-388\end{array}$ \\
\hline Copper & $\begin{array}{l}63 \\
65\end{array}$ & $\begin{array}{c}99 \\
91-99\end{array}$ & $\begin{array}{c}2 \\
2-4\end{array}$ \\
\hline Zinc & $\begin{array}{l}67 \\
68 \\
70\end{array}$ & $\begin{array}{l}7694 \\
37-99 \\
65-88\end{array}$ & $\begin{array}{rl}18 & 44 \\
2 & 8 \\
110 & 400\end{array}$ \\
\hline Selenium & $\begin{array}{l}74 \\
76 \\
77 \\
82\end{array}$ & $\begin{array}{rr}31 & -99 \\
74 & 99 \\
68 & 94 \\
73 & 99\end{array}$ & $\begin{array}{c}98-714 \\
6-27 \\
30-32 \\
20-45\end{array}$ \\
\hline
\end{tabular}

1 Oak Ridge National Laboratory, PO Box 2009, Oak Ridge, Tennessee 37831-8044, USA; AEA Technology, Building 10.30, Harwell, Oxfordshire OX11 0RA, UK; Europa Scientific, Europa House, Electra Way, Crewe, Cheshire CWI 1ZA, UK; Medgenix Diagnostics GmbH, Lisa-Meitner Str 4a, D-4030 Ratingen I, Germany. At the time of writing the costs of isotopes are very volatile.

\section{STABLE ISOTOPE QUANTIFICATION}

Stable isotopes are naturally present in the body; therefore natural isotopic abundance and the degree of required enrichment in the body fluids that are going to be measured are very important considerations when planning studies of mineral absorption. Two approaches are available to measure stable isotopic enrichment, namely neutron activation analysis and mass spectrometry. Both include well established methods for the quantitative measurement of isotopes in many different matrices.

\section{Neutron activation analysis $(N A A)$}

Although the technique of neutron activation has mostly been used for total element analysis, many of the earlier studies on mineral bioavailability utilized NAA to quantify isotopic enrichment (King et al. 1978; Janghorbani et al. 1980; Fairweather-Tait et al. 1983). Neutron activation is based on the interaction of thermal neutrons from a medium to high flux nuclear reactor with the nuclei of stable isotopes. It is not suitable for the measurement of every stable isotope, since the nuclear transformation must result in eventual production of a radioactive nuclide capable of emitting suitable radiation that can be measured with a $\mathrm{Ge}(\mathrm{Li})$ detector coupled to a multichannel analyser.

In measuring isotopic abundances with NAA, some elements (e.g. ${ }^{70} \mathrm{Zn}$ ) require extensive pre- and post-radiochemical separation. Determination of isotopes in biological fluids 
results in the production of very large amounts of radioactivity from matrix components such as $\mathrm{Cl}$, Na and $\mathrm{K}$, which cause interference. Fortunately these possess half-lives of less than $15 \mathrm{~h}$ so if samples are allowed to decay for $1-2$ weeks, isotopes such as ${ }^{59} \mathrm{Fe}$ can be readily measured.

The overall precision with which isotopic measurements can be carried out by NAA is governed by the uncertainties associated with each step of the procedure. Thus, for iron, where almost no sample preparation is required, RSD (relative standard deviations, i.e. $($ standard deviation $/$ mean) $\times 100$ ) approaching $1 \%$ are common. However, for zinc where extensive pre- and post-irradiation cleanup is required, the RSD may be as high as $5 \%$ (Janghorbani \& Young, 1982).

\section{Thermal ionization mass spectrometry (TIMS)}

Magnetic sector (separates masses in a magnetic field) TIMS has been used for many years by analysts, geochemists, and nuclear chemists to determine isotopic abundances and to quantify minerals by isotope dilution. It was first used for nutrition related research by Rabinowitz et al. (1973) in a study of lead metabolism. Since then the absorption of copper (Turnlund et al. 1982a) and zinc and iron (Turnlund et al. 1982b) have been measured using TIMS with high precision (with RSD of less than $0.1 \%$ ) but slow sample throughput, typically $2-3$ samples per $24 \mathrm{~h}$.

In 1980 a modified TIMS approach was successfully employed to measure calcium isotope ratios (Yergey et al. 1980) using a quadrupole (which separates masses by applying alternating and constant voltages to rods connected in parallel) mass spectrometer equipped with a thermal ionization source. In recent years a quadrupole instrument has become commercially available which is less expensive than magnetic sector machines and is capable of analysing up to 26 samples per $24 \mathrm{~h}$ but with a lower precision (RSD approximately $0 \cdot 5-1 \%$ ).

Magnetic sector instruments have improved in recent years, and are now equipped with multiple sample turrets and collector detection systems, but analysis is still slower than most other methods, and samples must be free from organic material and interfering elements. Commonly used purification methods include ion exchange, solvent extraction and electrodeposition. The loading of the sample on to the filament is critical, and has been shown to affect the stability and size of the ensuing current. Samples are gently heated by passing a carefully controlled current through the filament, whereupon vaporization, dissociation and ionization occur to produce intense stable ion emission, from which isotope ratio measurements are made. TIMS is expected to continue as the method of choice when the highest precision is required.

\section{Fast atom bombardment mass spectrometry (FABMS)}

FABMS is more widely available than TIMS, its sensitivity is good for some minerals and analysis is much faster. However, FABMS does not have the precision of TIMS (typical RSD are $1 \%$ ), nor the multielement coverage of inductively coupled plasma mass spectrometry (ICPMS). Isobaric interferences from other isotopes can be a problem and require high resolution mass spectrometry (Self et al. 1987). In FABMS, samples are bombarded with argon or xenon atoms, and the sputtered charged species are separated in the mass analyser. With a medium resolution instrument it is very easy to separate most organic compounds from metal ions because of the fractional mass difference between them. Precision and accuracy of FABMS have not yet been fully evaluated for all minerals, but good agreement has been found in results published so far (Eagles et al. 1989). Although raw isotopic ratios do not agree with literature values because of a number of 
instrumental factors, these can be corrected by measuring the isotopic ratios of known standards.

\section{Inductively coupled mass spectrometry}

ICPMS appears to have considerable potential for absorption studies using inorganic isotopes. It is also a promising means of studying mineral speciation. The commercial instruments now available are more competitive in price and analysis is faster. Less sample preparation is required and in some instances isotopic ratios of several minerals can be measured in a single sample.

Samples are introduced into a high temperature argon plasma produced by electrical discharge, where the solids are volatilized and then ionized. The gaseous plasma is sampled at atmospheric pressure through a differentially pumped interface and ions are mass analysed by a quadrupole mass spectrometer (high resolution magnetic sector mass spectrometers have also recently been coupled to this type of ion source). Current limitations include poor nebulization efficiency, so sample volumes of about $10 \mathrm{ml}$ per mineral are required, and there are isobaric interferences at low masses, notably ${ }^{40} \mathrm{Ar}^{+}$from the plasma with ${ }^{40} \mathrm{Ca}^{+}$. Figures for precision with ICPMS in absorption studies have been reported to be $0.33-0.84 \%$ RSD for zinc (Egan et al. 1991), 0.35 and $0.1 \%$ for iron (Janghorbani et al. 1986; Fomon et al. 1988).

\section{Electron impact mass spectrometry (EIMS) and gas chromatography mass spectrometry $(G C M S)$}

Schwartz \& Giesecke (1979) developed a method for measuring ${ }^{26} \mathrm{Mg}$ using a volatile magnesium chelate. Although this method was superior to NAA, higher than desirable enrichments of ${ }^{26} \mathrm{Mg}$ were required for best precision. This paper is reported to mark the beginning of the mass spectrometry era for research with stable isotopes (Turnlund, 1989).

EIMS and GCMS have the major advantage that the instrumentation is available in many laboratories. They require that a volatile chelate of the metal be prepared. Unfortunately lack of suitable chelates for some minerals, memory problems and limited precision and accuracy restrict their use. However, their sensitivity has been reported to be superior to NAA for zinc, copper and iron (Johnson, 1982), and GCMS (Reamer \& Veillon, 1981) and negative TIMS (Heumann \& Rädlein, 1989) appear to be promising techniques for selenium.

\section{PREPARATION AND ADMINISTRATION OF STABLE ISOTOPES}

The isotope is normally obtained as the metal itself or its oxide, although calcium is available mainly in the carbonate form. The isotope must be converted into a suitable form before administration. The chemical form in which the mineral isotope is administered depends on the study but it is usually a soluble salt such as the chloride or sulphate obtained by dissolving in the corresponding dilute acid. Selenium is usually converted to selenite.

\section{Dosage considerations}

A stable isotope, unlike a radioisotope, is universally present in the body tissues. When designing a stable isotope study therefore the basic requirement is to achieve a sufficient isotope enrichment in the body tissue/fluid of interest so that the added tracers can be quantified with the necessary degree of precision. The amount of isotope added depends on four major factors. 
(1) The amount of expected absorption and retention. This varies widely with different elements. Fe absorption, for example, can vary from $<1 \%$ to almost $100 \%$ depending on the $\mathrm{Fe}$ status of the subject and the meal composition, whereas $\mathrm{Zn}$ absorption would normally be in the range 10-30\%, Ca absorption from 20 to $40 \%$ and Se absorption about $80 \%$. Virtually all the Fe absorbed is retained and only a small portion of absorbed $\mathrm{Zn}$ is excreted into the urine. The urinary excretion of $\mathrm{Ca}$ and $\mathrm{Se}$, however, is much higher.

(2) Relative distribution between different body tissues and fluids. The total body content of different minerals (and thus their constituent stable isotopes) varies widely as does their distribution between the different body compartments and fluids. For example, while some $60 \%$ of the body's $2.3 \mathrm{~g}$ of $\mathrm{Zn}$ is in the muscle only $0.1 \%$ is in the blood plasma. In comparison about $60 \%$ of the body's $4 \mathrm{~g}$ of $\mathrm{Fe}$ is in the red blood cell haemoglobin. It is essential to know the amount of mineral naturally present in urine, stool and blood if these pools are to be enriched.

(3) The natural abundance of the isotope administered. The higher the natural abundance, the greater the quantity of isotope which must be administered to detect an enrichment.

(4) The degree of isotope enrichment required. This depends on the precision of the instrument. It is customary to set the detection limit for measured isotope ratio shifts at 3 times the SD of the baseline ratio measurement. With the quadrupole TIMS this corresponds to a minimum $3.9 \%$ enrichment for ${ }^{58} \mathrm{Fe}$ in red blood cell haemoglobin. In practice, however, there are large individual variations for the absorption for different subjects. Enough isotope has to be administered to obtain the minimum enrichment for all subjects. This can be achieved by administering a dose which gives an average isotope ratio shift of approximately 10 SD. For the quadrupole TIMS this means an enrichment of $10 \%$ for ${ }^{58} \mathrm{Fe}$.

\section{Intrinsic or extrinsic tag}

The measurement of mineral bioavailability from foods can be made by labelling the food intrinsically (biological incorporation of the isotope) or extrinsically (mixing the isotope with the food). Plant foods can be labelled intrinsically by adding the isotope to the nutrient solution of hydroponically grown plants, by direct injection, or by foliar application (Weaver, 1985). Animal tissue may likewise be intrinsically labelled by adding the isotope to the diet, administering by gavage, or injecting either intravenously, intraperitoneally or intramuscularly. Because of their high cost, efficiency of label incorporation is of utmost importance with stable isotopes and care should be taken that the isotope is incorporated in its natural form into edible parts of the plant or animal. Efficiency of incorporation of ${ }^{68} \mathrm{Zn}$ and ${ }^{70} \mathrm{Zn}$ into chicken meat was only $2-3 \%$ (Janghorbani et al. $1981 \mathrm{a}$ ) compared to $18 \%$ incorporation of ${ }^{70} \mathrm{Zn}$ into soyabean seeds (Janghorbani et al. 1983).

The use of tracers added extrinsically to meals prior to feeding is vastly simpler and less expensive than using intrinsically labelled food. With this approach, it is assumed that the extrinsic tag exchanges completely with the native mineral and that they are absorbed and metabolized in an identical manner. This has been shown to be the case for extrinsic radioactive tags of $\mathrm{Fe}$ and $\mathrm{Zn}$ (Weaver, 1988). With few exceptions, all species of non-haem food Fe enter a common pool in the gastric juice together with the food ligands which enhance or inhibit Fe absorption.

Exchange of stable isotopes with native minerals takes longer and could therefore be more difficult since, unlike with radioisotopes, the tag represents a much larger part of the total mineral pool. However, most recent studies in humans using mass spectrometric techniques have found a good agreement between intrinsically and extrinsically added 


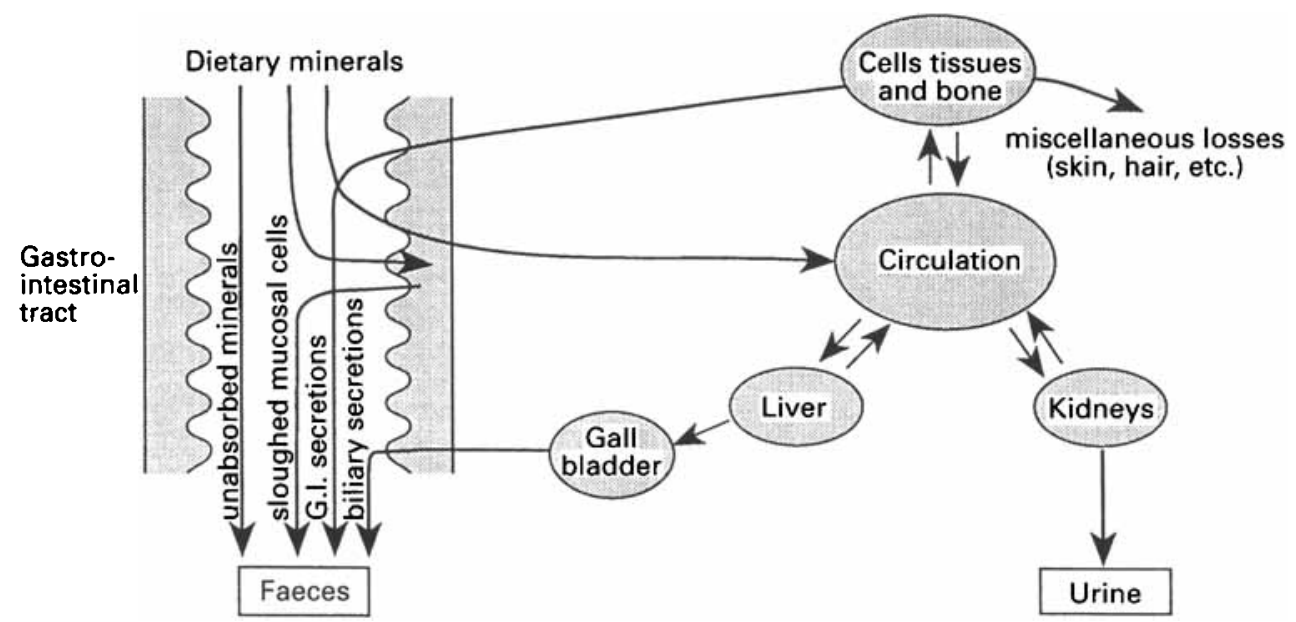

Fig. 1. Principles of mineral and trace element metabolism.

tracers of $\mathrm{Zn}, \mathrm{Ca}, \mathrm{Mg}$ and $\mathrm{Cu}$. $\mathrm{Zn}$ absorption from intrinsically and extrinsically labelled cows' milk based infant formulas was identical for infants (Serfass et al. 1989) and for adult women (Egan et al. 1991) as was the absorption of $\mathrm{Ca}$ and $\mathrm{Mg}$ by low birth weight infants fed intrinsically or extrinsically labelled breast milk (Liu et al. 1989). Similarly the absorption of intrinsically and extrinsically added $\mathrm{Ca}$ was not significantly different in adults fed whole wheat flour (Weaver et al. 1992) or milk (Martin et al. 1989), and equal absorption of intrinsically and extrinsically added copper has been reporied from goose meat, goose liver, peanut butter and sunflower butter (Johnson et al. 1988).

Some groups, however, have reported differences in absorption between intrinsic and extrinsic tags. The small differences (extrinsic tag absorption was $0.8-0.9$ of intrinsic tag) reported by Janghorbani et al. (1982b) for chicken muscle could, however, have been due to problems with neutron activation analysis (Serfass et al. 1989). Studies in rats (Fairweather-Tait et al. 1991) resulted in even bigger differences in absorption between the labels added intrinsically or extrinsically indicating incomplete equilibration in the gut. The reasons for this discrepancy are unknown although insufficient time for equilibration of the extrinsic tag with the native mineral prior to feeding would seem a possibility. Similarly, Christensen et al. (1983) have reported big differences in the absorption of intrinsic and extrinsic Se labels (extrinsic $=0.5$ of intrinsic) in chicken muscle intrinsically labelled with ${ }^{74} \mathrm{Se}$ and fed with an extrinsic tag of ${ }^{76} \mathrm{Se}$ (selenite), although absorption of the two labels was similar from egg (Sirichakwal et al. 1985). The reason for these anomalous results for Se are unclear although the possibility that inorganic Se (selenite, selenate) and organic Se (selenomethionine, selenocystine) are absorbed in different ways from two separate pools cannot be ruled out. This would be analogous to the haem and non-haem Fe pools. If two absorptive pools of Se did exist they would need to be labelled with different tracers.

Intrinsic versus extrinsic labelling studies have not been made with $\mathrm{Fe}$ stable isotopes; however, the common pool theory would be expected to hold and any soluble Fe stable isotope would label the pool in a similar way to an extrinsic radioactive $\mathrm{Fe}$ tag. Extrinsic labelling assumes that common pools exist for all minerals and, indeed, $\mathrm{Fe}, \mathrm{Zn}, \mathrm{Ca}, \mathrm{Mg}$ and $\mathrm{Cu}$ from most foods would seem to enter common pools from which absorption can be measured by extrinsically labelling with stable isotopes. Care should be taken that the extrinsic tag has time to equilibrate fully with the native mineral and the amount of mineral added with the tag needs careful consideration as this influences the size of the total mineral 


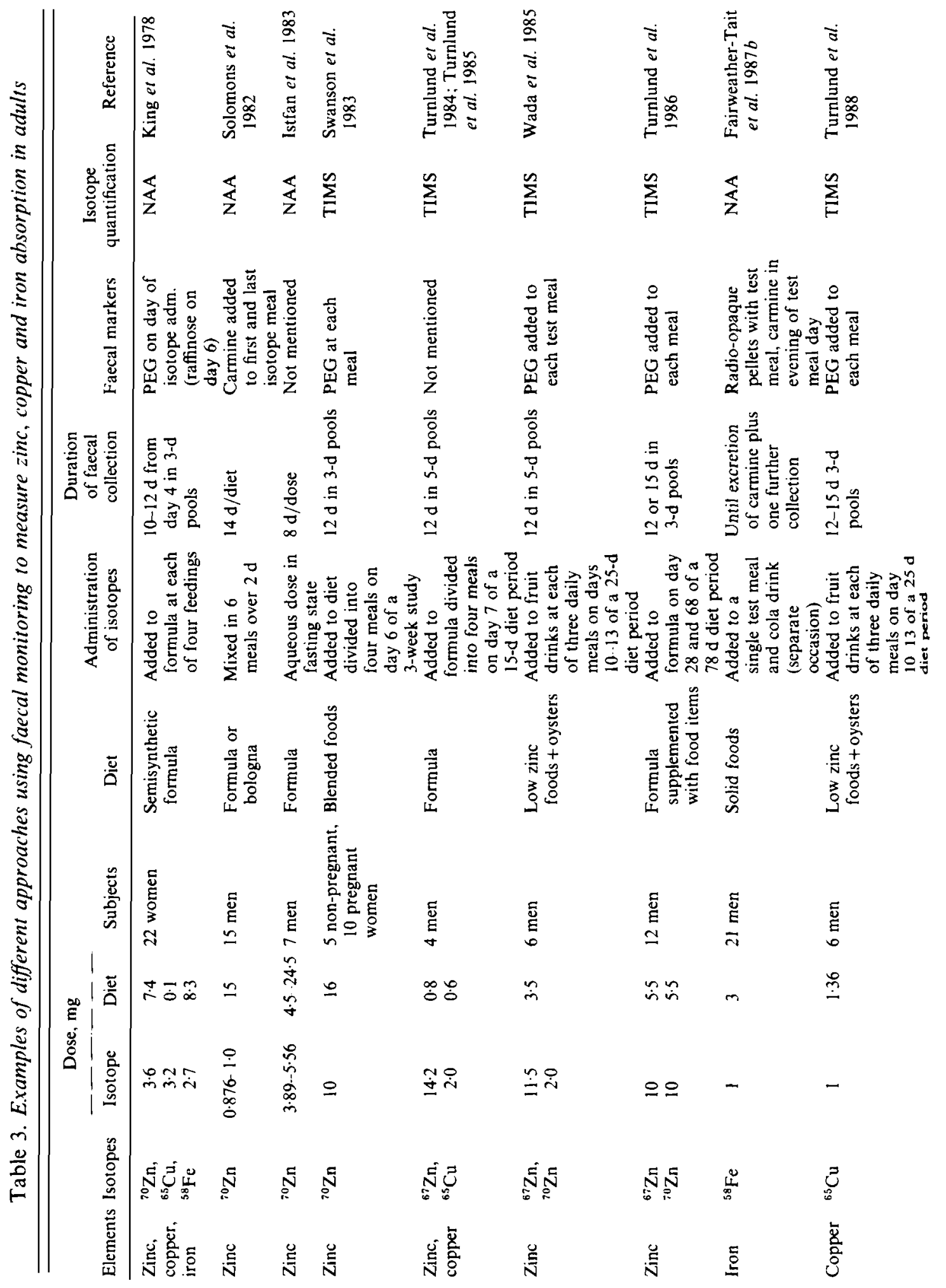




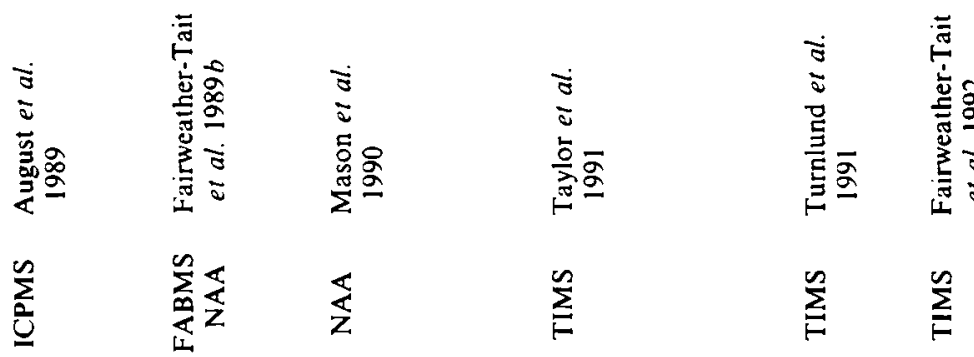

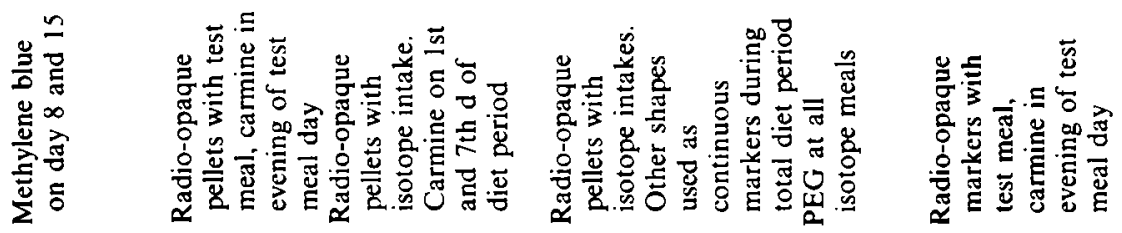

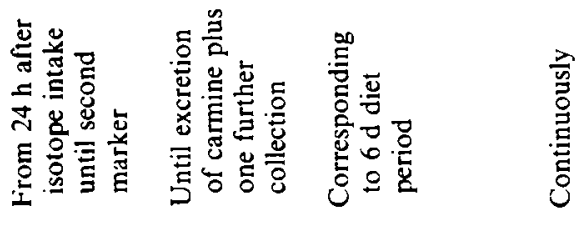

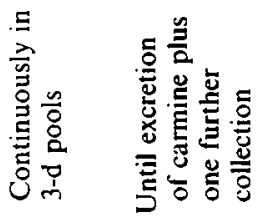

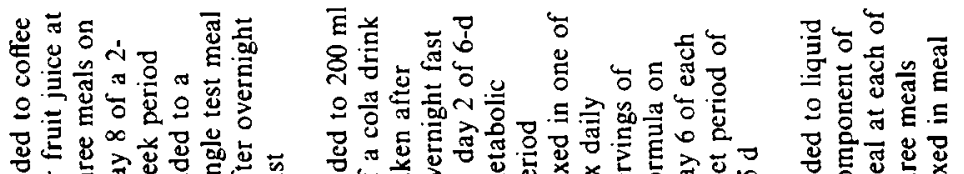

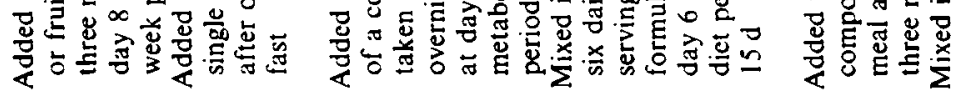<smiles>CC1CCCC1C</smiles>

焉

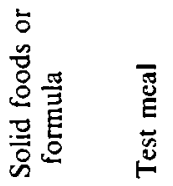

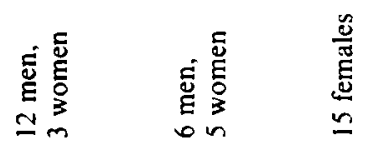

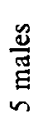

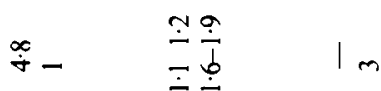

$\dot{m}$

$\infty$
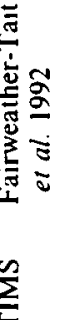
pool in the food. Measuring Se absorption by labelling meals extrinsically with Se stable isotopes still needs some clarification.

\section{GENERAL PRINCIPLES OF ABSORPTION STUDIES}

In order to understand fully the necessity for isotopic techniques to measure mineral bioavailability, we must first consider the basic features of mineral metabolism (Fig. 1). When a mineral is consumed with food, a portion of that mineral is absorbed and passes into the blood circulation, while the non-absorbed portion passes through to the faeces. From the circulation, some of the absorbed mineral will pass into the body tissues and some will be excreted in the urine. A second excretory pathway is from the body tissues back into the gut via the bile or gastrointestinal secretions. This could include a small fraction of the dietary mineral recently absorbed, but is mostly mineral already present in the body. Although some of this endogenous mineral can be reabsorbed, the larger fraction passes into the stools. The bioavailable mineral is that mineral from the food which is absorbed and retained in the body.

As already mentioned, the classical balance method, which compares the intake of a mineral with its total excretion, is not very useful for measuring mineral bioavailability because the faeces contain minerals from both food and endogenous origin. In addition, intestinal mixing occurs and dietary intake on one day may be excreted over several days (Turnlund, 1991). By using isotopic tracers, however, the metabolic fate of minerals in a particular meal or food can be followed by analysis of the isotope.

\section{STUDY TECHNIQUES}

\section{FAECAL MONITORING}

The principle for the faecal monitoring technique is the same as for the conventional chemical balance technique. Absorption is determined from the disappearance of the isotope during intestinal passage, calculated as the difference between intake and faecal content. This is so far the most commonly used technique to measure absorption. The advantage with this technique is that there is only a limited effect of intestinal re-excretion of the element; however, it possesses the disadvantage of the cumbersome collection of faecal samples. The first reported mineral absorption study using stable isotopes and faecal monitoring was published by King et al. (1978) and has later been followed by a number of studies measuring zinc, copper, selenium, calcium and magnesium absorption. The design of some recent studies of zinc, copper and iron absorption is summarized in Table 3 .

\section{Intestinal transit time and study length}

One of the crucial issues to establish for the protocols when using this method is the appropriate period needed for faecal collection, i.e. the minimum time to collect all nonabsorbed isotope without too great an addition of endogenously excreted isotope. The mouth to anus transit time through the gastrointestinal tract in humans shows considerable interindividual variation which is related to diet composition and genetic and physiological differences. Janghorbani et al. (1980) claim that transit time is complete following five stools. In contrast, Turnlund et al. (1988) report elimination of a non-absorbable marker for up to 18 days after administration to a young man. The colonic passage accounts for the major part of total transit time while small intestinal transit is less than $24 \mathrm{~h}$. This means 
that food residues from several days' intake are mixed in the colon. The faecal samples containing most of the non-absorbed isotope will therefore also contain initially absorbed and rapidly re-excreted isotope as well as endogenously excreted isotopes.

\section{Endogenously excreted elements}

The endogenous excretion of minerals and trace elements consists of non-absorbed elements from pancreatic, bile and other intestinal juices, and elements lost by sloughed cells. For zinc, copper, calcium and possibly also for selenium the endogenous losses are of the same magnitude as the amount absorbed (i.e. at least $20-30 \%$ of intake), while endogenous intestinal losses of iron are low. Absorbed isotopes of dietary origin will eventually equilibrate with body minerals in cells and tissues and the endogenously excreted elements will thus also be gradually 'labelled' with stable isotopes. The effect of this phenomenon on the estimate of absorption using the faecal monitoring technique is dependent on the body pool size, the turnover rate in different tissues and the degree of exchangeability. When the rate of endogenous excretion is known or simultaneously measured it can be used to correct calculated absorption values for excretion during the first days after intake of test dose. Measurements of whole body turnover after intravenous injection of a radioisotope of zinc show a rate of loss corresponding to approximately $14 \%$ over $14 \mathrm{~d}$ (Arvidsson et al. 1978), most of which is probably lost via the intestine. A similar endogenous excretion rate has been reported by Fairweather-Tait et al. (1992) by simultaneous oral and intravenous administration of two different stable zinc isotopes.

The excretion rate of a zinc isotope is higher during the first days after intravenous administration, most probably due to a higher specific activity of the isotope in intestinal secretions, before a more complete equilibrium between all easily exchangeable body zinc has occurred. This means that a single exponential extrapolation from the linear part of the excretion curve, after about one week, will slightly underestimate 'true' absorption. The initial rapid excretion of absorbed isotope can be accounted for by simultaneous oral and intravenous administration of two different isotopes (Fairweather-Tait et al. 1992). This approach is, however, best suited for studies of single meals, since multiple intravenous administrations make the kinetics complicated. Wastney \& Henkin (1989) have suggested a compartmental approach for data analysis that allows separate calculation of total, unabsorbed and absorbed excreted traces in faeces following an oral dose.

\section{Faecal markers}

To assure complete collection of unabsorbed isotopes and for identification of faecal samples in relation to dietary intake, unabsorbable substances can be used as faecal markers. The most commonly used are colouring agents (e.g. carmine), polyethylene glycol (PEG), radioisotopes of chromium $\left({ }^{51} \mathrm{CrCl}_{3}\right)$ and radio-opaque plastic markers.

(a) The colouring agents are mainly used to determine the time point when the collections can be completed, as they often give a diffuse distinction between dietary periods and can probably, at best, separate 3-d dietary periods of intake. These substances may be a potential source of trace element contamination.

(b) PEG is assumed to follow the solid phase of the meal. It is most often analysed by turbidimetric methods with rather poor precision and often less than $100 \%$ recovery. Detergent washed bran mordanted with chromium has been used together with PEG in studies of magnesium absorption (Schwartz et al. 1984). The recovery in $5 \mathrm{~d}$ after a test meal ranged from 52 to $100 \%$ with an average of $87 \pm 11 \%$. It was suspected that concentrations in some of the early or late faecal samples were below detection limits.

(c) The $\gamma$-emitting chromium isotope $\left({ }^{51} \mathrm{Cr}\right)$ has been used in conventional balance 
studies and can be analysed with high precision. It is however doubtful whether chromium is completely unabsorbed (Gibson et al. 1988). For elements with a low degree of absorption calculations based on rate of chromium excretion seem to introduce large errors (Davidsson et al. 1989).

(d) Radio-opaque plastic pellets and X-ray examination of fresh or lyophilized faecal samples offer a simple means to determine when faecal collection can be considered complete and furthermore a way to determine which faecal samples to process for stable isotope determinations. They can be administered in different geometrical forms in gelatin capsules together with the isotope-labelled meals or diets. As they are available in different shapes they can also be used to separate diet periods or as continuous markers for intestinal transit. Most of the recent studies of mineral and trace element absorption use radioopaque pellets as faecal markers of isotope transit, in some instances with carmine as marker for the end of the collection period.

An alternative approach to determine trace element absorption from faecal isotope excretion has been developed and initially used in a study of lactating women (Jackson $e t$ al. 1984, 1988). Enrichment of the exchangeable body pool of zinc by infusion of stable isotopes and measurements of total zinc and stable isotope enrichment in plasma and faeces during a period of constant diet intake allow estimates of endogenous zinc excretion and correction of apparent zinc absorption. This method could theoretically be ideal for determining the overall effects of different types of diets. However, the general problem of faecal collections and the need to relate faecal samples to period of dietary intake remains.

\section{Application of the faecal monitoring technique in adults for individual elements}

Zinc, copper and iron (Table 3). Most studies using the faecal monitoring technique for measuring zinc absorption in adults have used ${ }^{70} \mathrm{Zn}$ or ${ }^{67} \mathrm{Zn}$. In the early studies, especially when the isotopes were quantified with NAA, rather high levels were given, sometimes corresponding to $100 \%$ of normal mineral intake. Improved analytical techniques have reduced added levels to approximately 10-20\% of native element content. The high natural abundance of available stable isotopes of copper limits their use as tracer. Levels corresponding to $50-100 \%$ of typical daily intakes have been applied in most studies. Of the available stable isotopes of iron ${ }^{54} \mathrm{Fe}$ and ${ }^{58} \mathrm{Fe}$ have been used at levels corresponding to $30-60 \%$ of diet content.

Magnesium. Available radioisotopes of magnesium have half-lives that are too short to be useful in absorption studies in humans. Only a few studies of magnesium absorption using stable isotopes have so far been published. Schwartz et al. $(1978,1984)$ added $50 \mathrm{mg}$ of ${ }^{26} \mathrm{Mg}$ to diets containing $150-350 \mathrm{mg}$ total magnesium. The urine and faecal samples were analysed by mass spectrometry of a chelate $\mathrm{Mg}\left(2,2^{\prime}, 6,6^{\prime}\right.$-tetramethyl-3,5-heptanedione) $)_{2}$.

Selenium. Selenium offers a number of suitable stable isotopes, with regard to natural abundance, but also an analytical challenge due to the low natural levels. Doses in the order of $100-400 \mu \mathrm{g}$ of ${ }^{74} \mathrm{Se}$ or ${ }^{76} \mathrm{Se}$ have been used (Sirichakwal et al. 1985; Mangels et al. 1990; Martin et al. 1988) which is equal to or above the total daily intake in many countries.

Infant studies. The safe, non-invasive characteristics of the faecal monitoring technique have special relevance for studies of absorption in infants. When stable isotopes are used to study absorption from infant formulas and foodstuffs to which minerals/trace elements are routinely added, the stable isotopes can be used in their place, thus avoiding the problems associated with adding additional element (in the form of a label). Zinc, copper, iron, magnesium and calcium absorption have been studied in infants using the faecal monitoring approach (Fairweather-Tait et al. 1987 a; Ehrenkranz et al. 1989; Liu et al. 1989; Serfass et al. 1989; Ziegler et al. 1989). The usual protocol is to add the isotope to 
a meal or divided diet administered over $24 \mathrm{~h}$ and collect faecal samples over $72 \mathrm{~h}$. Carmine and activated charcoal have been used as markers.

\section{TISSUE RETENTION}

The tissue retention method can be used only if the mineral is incorporated to a high extent into a specific tissue or body compartment. In practice, it is used exclusively to measure the incorporation of $\mathrm{Fe}$ into haemoglobin. Since newly absorbed $\mathrm{Fe}$ is primarily used for haemoglobin synthesis, Fe bioavailability from a specific food or test meal can be determined by measuring the incorporation of an $\mathrm{Fe}$ isotope into red blood cell haemoglobin. A radioiron technique based on this principle is routinely used for measuring $\mathrm{Fe}$ absorption in adults (Hallberg, 1981). Incorporation of the isotope into haemoglobin is measured in a blood sample taken $14 \mathrm{~d}$ after ingestion of the labelled test meal. Fe absorption is calculated from blood volume (estimated from height and weight), and an assumed red cell incorporation of absorbed radioiron of $80 \%$ (Hosain et al. 1967). The extent of Fe absorption from a particular food, however, depends on two major factors. One is the level of absorption inhibitors and enhancers in the food, and the other is the $\mathrm{Fe}$ status of the subject. To overcome the influence of Fe status, comparisons between different meals are usually made within the same subjects by administering two different radioisotopes $\left({ }^{59} \mathrm{Fe}\right.$ and $\left.{ }^{55} \mathrm{Fe}\right)$ with different test meals served on consecutive days.

A stable isotope technique using ${ }^{58} \mathrm{Fe}$ as a label was developed by Fomon et al. (1988) to measure $\mathrm{Fe}$ absorption in infants. This method involves the administration of an ${ }^{58} \mathrm{Fe}$ tag with the test meal followed by a blood sample $14 \mathrm{~d}$ later for measurement of the incorporation of the stable isotope into haemoglobin. Absorption is calculated assuming a $90 \%$ incorporation of absorbed Fe. The method was subsequently used to measure $\mathrm{Fe}$ absorption in infants from a variety of Fe fortified infant foods (Fomon et al. 1989). As with adults, there was a large variation in Fe absorption between subjects with different $\mathrm{Fe}$ status, indicating that comparisons between different foods should be made within the same subject. This is possible with a single isotope only if there is a time lapse of $14 \mathrm{~d}$ between administrations. However, as with radioisotopes, a double isotope technique is preferable. Such a method has recently been reported (Kastenmayer et al. 1993; Wharf et al. 1993) using ${ }^{58} \mathrm{Fe}$ and ${ }^{57} \mathrm{Fe}$ in different meals fed to the same infant on consecutive days. This study design avoids the potential problem of changing Fe status in the rapidly growing child.

A further approach to overcome the problems associated with measuring Fe absorption in subjects of different Fe status is to measure Fe absorption from a reference dose and to correct the measured absorption from the test meal to a standard reference dose absorption. The absorption of a reference dose of $3 \mathrm{mg}$ radioiron as ferrous sulphate with $18.9 \mathrm{mg}$ ascorbic acid in $50 \mathrm{ml}$ water is often used in radioiron studies in adults. The measured absorption for test meals can then be connected to a $40 \%$ reference dose absorption which is common for subjects for borderline Fe stores (Hallberg, 1981). A similar approach can be used for stable isotope studies. With the double isotope technique in infants, a third isotope $\left({ }^{54} \mathrm{Fe}\right)$ can be used to label the reference dose (P. Kastenmayer, L. Davidsson \& R. F. Hurrell, unpublished).

A major restraint when using stable isotopes to measure Fe absorption is the quantity of isotope that must be added to the test meal to obtain sufficient enrichment in the red blood cells for mass spectrometric analysis. With the recently developed double isotope technique, $1.2 \mathrm{mg}{ }^{58} \mathrm{Fe}$ and $5 \mathrm{mg}{ }^{57} \mathrm{Fe}$ were administered to 6-month-old infants to measure satisfactorily a $5 \%$ absorption using a quadrupole TIMS (Kastenmayer et al. 1993). A similar quantity of ${ }^{58} \mathrm{Fe}(0.85 \mathrm{mg})$ must be administered to infants if ICPMS is used (Fomon et al. 1989). These amounts of tracer, especially ${ }^{57} \mathrm{Fe}$, represent a large part of the infants' 
daily $\mathrm{Fe}$ intake $(\sim 10 \mathrm{mg}$ ). This method is most useful therefore for measuring the absorption of fortification Fe. When measuring the absorption of native Fe from home prepared foods, the isotopes must be fed over several meals or several days to avoid representing too great a proportion of the total food Fe.

With adults, it is more difficult to measure the absorption of native food Fe from a single meal with stable isotopes using the haemoglobin incorporation method. With the quadrupole TIMS, for instance, $12 \mathrm{mg}{ }^{58} \mathrm{Fe}$ and $50 \mathrm{mg}{ }^{57} \mathrm{Fe}$ must be administered to a $70 \mathrm{~kg}$ adult to measure $5 \%$ absorption with satisfactory precision. The ${ }^{57} \mathrm{Fe}$ administration is 5 times the recommended daily allowance of an adult male. The isotopes could be fed over a series of meals or days, or the quantity of isotope administered could be reduced either by increasing Fe absorption (by adding absorption enhancers) or by using a mass spectrometer of higher precision (e.g. magnetic sector TIMS). Barrett et al. (1992) recently reported a $10-34 \% \mathrm{Fe}$ absorption in women from an Fe-fortified orange juice containing $5 \mathrm{mg}{ }^{57} \mathrm{Fe}$ and fed on two occasions. The high cost of Fe stable isotopes, however, makes absorption studies more feasible in infants than in adults.

Measuring the absorption of other mineral elements by tissue retention is more difficult due to problems of access to the major tissue pools. Red blood cells are only a minor pool for zinc and selenium. With zinc for instance they contain $<3 \%$ of total body zinc; however, orally administered ${ }^{70} \mathrm{Zn}$ can be quantified in red blood cells (Wastney et al. 1991) and provided that a fixed amount of newly absorbed zinc is always distributed to this tissue, zinc absorption could theoretically be measured by tissue retention.

\section{SIMULTANEOUS ORAL AND INTRAVENOUS ADMINISTRATION}

\section{Calcium}

A relatively simple double isotope procedure for measuring true calcium absorption has been developed using two stable isotopes of calcium (Smith et al. 1985; Yergey et al. 1987). The use of oral and intravenous isotopes was first described by Garner et al. (1960), and the possibility of its use in humans discussed by Bronner (1962). The stable isotope method has been modified from one using two radioisotopes (Aubert et al. 1963; DeGrazia et al. 1965; Roth \& Werner, 1985), or one stable and one radioisotope (Neer et al. 1978).

Absorption is determined from the ratio of the specific activities of orally (e.g. $\left.{ }^{44} \mathrm{Ca}\right)$ and intravenously (e.g. ${ }^{42} \mathrm{Ca}$ ) administered isotopes in a plasma or urine sample taken $24 \mathrm{~h}$ after simultaneous administration of the isotopes:

$$
\text { Absorption }=\frac{\text { na }{ }^{44} \mathrm{Ca}}{n a^{42} \mathrm{Ca}} \times \frac{{ }^{42} \mathrm{Ca} \text { i.v. }}{{ }^{44} \mathrm{Ca} \text { oral }} \times \frac{\% \mathrm{XS}^{44} \mathrm{Ca}}{\% \mathrm{XS}^{42} \mathrm{C}} \times 100 \%
$$

where na $=$ natural abundance of the isotope (atom \%); i.v. and oral $=$ doses of isotopes administered $(\mathrm{mg})$; and $\% \mathrm{XS}=[$ (measured ratio-natural abundance ratio)/natural abundance ratio] $\times 100$.

The isotopes generally used for this method are ${ }^{44} \mathrm{Ca}$ for oral dosing, and ${ }^{42} \mathrm{Ca}$ or ${ }^{46} \mathrm{Ca}$ for intravenous administration. Choice depends upon cost (the lowest natural abundances are usually more expensive and less highly enriched) and the method of detection. For example, when measuring isotope ratios by TIMS there are background ions present at $\mathrm{m} / \mathrm{z}$ 43 which interfere with the measurement of ${ }^{43} \mathrm{Ca}$ (Yergey et al. 1980).

Dose depends upon body size, metabolism of calcium, and the sensitivity and standard deviation of the isotope ratio measurement. The aim is to give the minimum dose of isotope to obtain urine (or plasma) that is adequately enriched for the accurate determination of 
Table 4. Oral (o) and intravenous (i.v.) doses of calcium isotopes used in double label absorption studies

\begin{tabular}{|c|c|c|c|c|}
\hline Subject(s) & Isotope & Technique & Dose & Reference \\
\hline Adult & $\begin{array}{l}{ }^{44} \mathrm{Ca} 0 \\
{ }^{42} \mathrm{Ca} \text { i.v. }\end{array}$ & ${ }^{\text {a FDM }}$ & $\begin{array}{r}185.4 \mathrm{mg} \\
27.3 \mathrm{mg}\end{array}$ & Lehmann \& Kessler (1982) \\
\hline Adult man & $\begin{array}{l}{ }^{44} \mathrm{Ca} \mathrm{o} \\
{ }^{42} \mathrm{Ca} \text { i.v. }\end{array}$ & ${ }^{\mathrm{B}} \mathrm{FABMS}$ & $\begin{array}{c}13 \mathrm{mg} \\
4 \mathrm{mg}\end{array}$ & Smith et al. (1985) \\
\hline Premature infants & $\begin{array}{l}{ }^{44} \mathrm{Ca} o \\
{ }^{46} \mathrm{Ca} \text { i.y. }\end{array}$ & "TIMS & $\begin{array}{l}1.25 \mathrm{mg} / \mathrm{kg} \\
7.5 \mu \mathrm{g} / \mathrm{kg}\end{array}$ & Hillman et al. (1988) \\
\hline Adolescents & $\begin{array}{l}{ }^{44} \mathrm{Ca} \mathrm{o} \\
{ }^{42} \mathrm{Ca} \text { i.v. }\end{array}$ & FABMS & $\begin{array}{l}21.8 \mathrm{mg} \\
3.6 \mathrm{mg}\end{array}$ & Miller et al. (1988) \\
\hline Children & $\begin{array}{l}{ }^{44} \mathrm{Ca} \text { o } \\
{ }^{42} \mathrm{Ca} \text { i.v. }\end{array}$ & FABMS & $\begin{array}{l}35 \mathrm{mg} \\
4.6 \mathrm{mg}\end{array}$ & Miller et al. (1989) \\
\hline Adults & $\begin{array}{l}{ }^{44} \mathrm{Ca} o \\
{ }^{42} \mathrm{Ca} \text { i.v. }\end{array}$ & FABMS & $\begin{array}{r}30 \mathrm{mg} \\
3 \mathrm{mg}\end{array}$ & Fairweather-Tait et al. (1989a) \\
\hline Adult women & $\begin{array}{l}{ }^{44} \mathrm{Ca} o \\
{ }^{42} \mathrm{Ca} \text { i.v. }\end{array}$ & TIMS & $\begin{array}{r}10 \mathrm{mg} \\
2 \mathrm{mg}\end{array}$ & Moser-Veillon et al. (1989) \\
\hline Premature infants & $\begin{array}{l}{ }^{44} \mathrm{Ca} \mathrm{o} \\
{ }^{46} \mathrm{Ca} \text { i.v. }\end{array}$ & TIMS & $\begin{array}{l}0.5 \mathrm{mg} / \mathrm{kg} \\
7.5 \mu \mathrm{g} / \mathrm{kg}\end{array}$ & Yergey et al. (1990) \\
\hline $\begin{array}{l}\text { Children } \\
\text { Adults }\end{array}$ & $\begin{array}{l}{ }^{44} \mathrm{Ca} \mathrm{o} \\
{ }^{42} \mathrm{Ca} \text { i.y. }\end{array}$ & TIMS & $\begin{array}{l}0.5 \mathrm{mg} / \mathrm{kg} \\
0.6 \mathrm{mg} / \mathrm{kg}\end{array}$ & Yergey et al. (1990) \\
\hline Adult male & $\begin{array}{l}{ }^{44} \mathrm{Ca} o \\
{ }^{42} \mathrm{Ca} \text { i.v. }\end{array}$ & TIMS & $\begin{array}{l}8 \mathrm{mg} \\
1.5 \mathrm{mg}\end{array}$ & Price et al. (1990) \\
\hline Adult female & $\begin{array}{l}{ }^{44} \mathrm{Ca} \mathrm{o} \\
{ }^{42} \mathrm{Ca} \text { i.v. }\end{array}$ & TIMS & $\begin{array}{l}5.2 \mathrm{mg} \\
0.8 \mathrm{mg}\end{array}$ & Price et al. (1990) \\
\hline
\end{tabular}

a Field desorption mass spectrometry.

b Fast atom bombardment mass spectrometry.

c Thermal ionization mass spectrometry.

fractional absorption from the oral dose. Any extra isotope will be an unnecessary cost, and may if given in very high levels perturb the normal metabolism of calcium. If the mass spectrometric technique is high precision thermal ionization (Price et al. 1990) then lower doses of oral and intravenous isotope can be used.

Various levels of dosing have been reported in the literature, as illustrated in Table 4 . In the summary of one of the original papers describing the double isotope method for measuring fractional absorption of calcium (Yergey et al. 1987) the doses given are $0.2-0.5 \mathrm{mg} / \mathrm{kg}{ }^{44} \mathrm{Ca}$ (oral) and $0.02-0.1 \mathrm{mg} / \mathrm{kg}{ }^{42} \mathrm{Ca}$ (i.v.). Studies in which higher levels of dosing are reported, such as that of Yergey et al. (1990), consist of more detailed investigations of calcium metabolism, which include the measurement of calcium absorption.

Zinc

Very recent work from Hambidge's group has indicated that fractional absorption of zinc can be determined from the measurement of isotopic enrichment in urine following oral and i.v. administration of stable isotopes of zinc (Friel et al. 1992). A pilot study was carried out in which ${ }^{70} \mathrm{Zn}$ (dose range $0.792-2.87 \mathrm{mg}$ ) was administered intravenously and ${ }^{68} \mathrm{Zn}$ (dose range $2.97-4.07 \mathrm{mg}$ ) orally to 4 adults. Isotopic enrichment of urine samples was determined from analysis by fast atom bombardment induced secondary ion mass spectrometry. Once the slopes of the isotopic disappearance curves in urine decline in a proportional manner it is possible to calculate fractional absorption (FA) from the oral dose as:

$$
\text { FA }=\text { enrichment (oral/i.v, }) \times \text { dose(i.v./oral) }
$$


The time at which FA reaches a plateau, $40 \mathrm{~h}$ post dosing, is somewhat later than that found for calcium (24 h post dosing, Yergey et al. 1990), which may reflect differences in zinc and calcium metabolism or age and body size of subjects. The decay curves (plasma and urine) are not smooth, and the authors point out that more work is required to improve the analytical technique and reduce sources of error. Fairweather-Tait et al. (1993) have also performed developmental studies on zinc kinetics using ${ }^{70} \mathrm{Zn}$ and TIMS and obtain smoother urinary and plasma isotopic decay curves.

\section{Magnesium}

True fractional absorption of magnesium could, in theory, be determined from urinary isotope measurements using the same principles as for calcium. When measuring magnesium absorption from vegetables Schwartz et al. (1984) gave $30 \mu \mathrm{Ci}{ }^{28} \mathrm{Mg}$ (radioisotope) intravenously and $50 \mathrm{mg}{ }^{26} \mathrm{Mg}$ (stable isotope) orally. However, they were unable to measure urinary isotope ratios because the ${ }^{26} \mathrm{Mg}$ enrichment was too low, and so had to use plasma ratios in blood taken up to $24 \mathrm{~h}$ post dosing. The high natural abundance of ${ }^{26} \mathrm{Mg}$ (and ${ }^{25} \mathrm{Mg}$ ) reduces the sensitivity with which magnesium stable isotopes can be measured in body fluids. With regard to the oral isotope, the precision could be enhanced by increasing the dose, but since fractional absorption varies inversely with the quantity consumed, the stable isotope dose should not exceed the amounts found in normal meals, that is a maximum of $150 \mathrm{mg}$.

\section{Selenium}

Simultaneous administration of isotopes of selenium has not yet been carried out, but initial studies by Martin et al. (1988) indicate that it should be technically feasible provided care is taken to use the appropriate chemical form and dose of selenium. Subjects were given $82 \mu \mathrm{g}$ selenium (average daily intake) as ${ }^{74} \mathrm{Se}$-selenite, either intravenously or orally, and urinary and faecal excretion and plasma disappearance of the isotope were measured in order to compare selenium kinetics, following the different routes of administration. Initially, selenium enrichment in the urine was greater than in the plasma indicating preferential excretion of the label before it has completely equilibrated with the exchangeable pools, but after $20 \mathrm{~h}$ urinary and plasma enrichment were equal, demonstrating that isotopic equilibration was achieved.

\section{PLASMA APPEARANCE}

\section{PLASMA TOLERANCE TESTS}

Plasma tolerance tests for mineral absorption studies have been used for many years. Basically the test involves the administration of a dose and subsequent measurement of the mineral in blood (plasma) at intervals of up to $6 \mathrm{~h}$ after administration. The increase in plasma mineral levels, usually expressed as the area under the curve above fasting level, is thought to give an indication of the absorption of the mineral.

The doses used in these studies to produce detectable increases of plasma concentrations often exceed the usual range of dietary intake. For zinc and iron amounts from $5 \mathrm{mg}$ up to $100 \mathrm{mg}$ have been applied, mostly in the form of zinc or iron sulphate. The amount of calcium applied is usually $1000 \mathrm{mg}$.

With stable isotopes of the element it is not necessary to achieve an increase in total plasma levels as the degree of isotope enrichment can be used as an indicator of absorption. Instead the sensitivity of the analytical method gives the minimum dose needed. A potential use of this method could be to compare different chemical forms of an element. 
Quantitative data for mineral absorption, however, cannot be obtained with a plasma tolerance test because plasma enrichment depends both on the rate of absorption and the plasma clearance rate.

Zinc

Janghorbani et al. $(1981 \mathrm{a}, c)$ gave a single dose of $3 \cdot 2 \mathrm{mg}$ of ${ }^{20} \mathrm{Zn}$ as $\mathrm{ZnCl}_{2}$, dissolved in a single glass of orange juice, in the fasting state to 4 healthy adult volunteers to measure the extent of ${ }^{70} \mathrm{Zn}$ enrichment in plasma samples. Venous blood samples were withdrawn from the antecubital vein every $15 \mathrm{~min}$ for the first two h, at $0.5 \mathrm{~h}$ intervals for the next $1.5 \mathrm{~h}$ and then hourly until $8 \mathrm{~h}$ after isotope ingestion. Two separate blood samples were also withdrawn immediately before isotope administration. A radiochemical neutron activation procedure for determination of ${ }^{68} \mathrm{Zn}$ and ${ }^{70} \mathrm{Zn}$ was applied for the blood samples.

In a study by Wastney et al. (1991) with 4 healthy volunteers (aged 47-66 years) zinc kinetics were compared after oral simultaneous administration of two tracers, radioactive ${ }^{65} \mathrm{Zn}$ and stable ${ }^{70} \mathrm{Zn}$ isotopes. The plasma appearance test was executed after an overnight fast and consisted of an oral dose of $1.99 \mathrm{mg}$ of stable ${ }^{70} \mathrm{Zn}$ (together with the radioactive tracer) in water. Venous blood samples were taken at $0.25,1,2,3$, and $5 \mathrm{~h}$ after administration. ${ }^{70} \mathrm{Zn}$ was determined by NAA. Various formulas are presented with regard to the calculation of the fraction of ${ }^{70} \mathrm{Zn}$ dose in the samples and of zinc absorption.

\section{Selenium}

Janghorbani et al. (1982a) studied selenium absorption in an experiment with four healthy male students. During the study period of $30 \mathrm{~d}$ the plasma tolerance test was executed twice. Each subject ingested $54.4 \mu \mathrm{g}{ }^{74} \mathrm{Se}$ in water. Immediately after isotope administration, blood samples were drawn every $0.5 \mathrm{~h}$ for $3 \mathrm{~h}$, hourly for the next $9 \mathrm{~h}$ and at 24,48 , and $96 \mathrm{~h}(8 \mathrm{ml} /$ blood sample $)$. On day 8 this procedure was repeated, but the oral dose was $108.8 \mu \mathrm{g}{ }^{74} \mathrm{Se}$. The isotope ${ }^{74} \mathrm{Se}$ was analysed by NAA. The mass isotope ratio ${ }^{74} \mathrm{Se} /{ }^{76} \mathrm{Se}$ of plasma was plotted against time.

Patterson et al. (1989) developed a model to describe the kinetics of sodium selenite metabolism in humans, based on plasma, urine and faeces samples obtained from six subjects over a 4-week period after a single oral dose of $200 \mu \mathrm{g}$ enriched ${ }^{74} \mathrm{Se}\left(77 \cdot 71 \%{ }^{74} \mathrm{Se}\right)$ as selenite in distilled deionized water. Blood was withdrawn immediately before the dose was administered and at $30 \mathrm{~min}, 60 \mathrm{~min}$, hourly for the next $7 \mathrm{~h}$ and then daily for the next $5 \mathrm{~d}$. For interpretation of results and kinetic modelling, cumulative curves were made with ${ }^{74} \mathrm{Se}$ ingested against time.

\section{DECONVOLUTION}

Some of the limitations of postabsorption plasma curves can be overcome if a second isotope is administered intravenously at the same time as the oral dose. Then the plasma activity curves of the two isotopic tracers can be analysed by the deconvolution technique to calculate fractional absorption from the oral dose, as described for calcium (Birge $e t$ al. 1969; Roth \& Werner, 1985) and zinc (Molokhia et al. 1980) using radioisotopes. The appearance of one isotope in blood after oral intake and the disappearance of a second isotope after intravenous injection over a period of not less than $3 \mathrm{~h}$ is measured, and from these data the fraction of the oral dose absorbed can be calculated.

Deconvolution is an established method for studying the absorption of drugs (Gibaldi \& Perrier, 1982) and radioisotopes, and computer programs are available to handle the data, but little work has been done so far using this technique with stable isotopes. Whittaker et al. (1989) used stable isotopes of iron, $0.187 \mathrm{mg}{ }^{57} \mathrm{Fe}$ intravenously and $5 \mathrm{mg}$ ${ }^{54} \mathrm{Fe}$ orally, to study absorption in women. Their approach was to collect blood samples 
every $30 \mathrm{~min}$ over $6 \mathrm{~h}$ and to measure the total area under the curve (AUC) of the logarithm of the enrichment in isotope ratio versus time for the oral: reference isotope (AUC $\mathrm{po}_{\mathrm{po}}$ ) and intravenous: reference isotope $\left(\mathrm{AUC}_{\mathrm{iv}}\right)$. They calculated oral absorption as follows:

$$
\text { Oral absorption }=\left(\mathrm{AUC}_{\mathrm{po}} / \mathrm{AUC}_{\mathrm{iv}}\right)\left(\text { dose }_{\mathrm{iv}} / \text { dose }_{\mathrm{po}}\right)
$$

A similar approach has been used for selenium by Martin et al. (1988) where two separate groups of subjects received an oral or intravenous dose of $61.7 \mu \mathrm{g}{ }^{74} \mathrm{Se}$.

\section{USE OF STABLE ISOTOPES FOR STUDIES OF MINERAL AND TRACE ELEMENT METABOLISM}

Stable isotopes can be employed to perform compartmental analysis and kinetic modelling (Shipley \& Clark, 1972). Examples of their use are in studies on zinc (Lowe et al. 1993; Fairweather-Tait et al. 1993), calcium (Abrams et al. 1992), selenium (Janghorbani et al. 1990), and lead (Rabinowitz et al. 1973). In all instances, isotopes have been introduced into the body by oral and/or intravenous routes, and the rate of appearance/disappearance in plasma and/or urine (also faeces in some studies) has been measured. The doses of isotopes are kept as small as possible so as not to perturb steady state conditions in the body, but the detection limits of the analytical technique used to determine isotopic enrichment in body fluids and the time course of the study have both to be taken into consideration when calculating the doses to be used.

Simple kinetic models can be developed from existing knowledge of the metabolism of the element under study. Rate constants describing the movement of the isotope between body pools are estimated and entered into the model. The differential equations are solved and when the estimated curve of isotope appearance/disappearance is identical to the measured data it is assumed that the correct rate constants have been selected. Exchangeable pool sizes and turnover rates can then be calculated (Fairweather-Tait et al. 1993).

Various computer programs have been written for mathematical modelling in experimental nutrition, including Mathcad, SAAM and CONSAM, but these vary greatly in their ease of use and applicability. It is extremely important that the differences between radioisotopic and stable isotopic tracer data analysis are appreciated. The fact that stable isotope tracers have a mass that is not negligible and are naturally present in the body, in contrast to radiotracers, means that a straightforward analogy between the two produces incorrect results. The mathematics of this problem are discussed and reviewed by Cobelli et al. (1987).

\section{CONCLUSIONS AND RECOMMENDATIONS}

No single technique for quantification and study design for measurement of absorption is optimal for all minerals and trace elements. Thus, when planning this type of study a careful evaluation of the objectives, including priority of element(s) to be studied and potential applications, including subjects (adults, children), single or multiple meals, total diets, supplements is necessary.

Researchers should draw up a list of questions to consider, such as

(a) is the dose physiological?

(b) is it sufficient to cause measurable enrichment?

(c) does the added isotope exchange with native food elements?

(d) what is the cost of the study?

(e) what analytical technique will be used, including isotope measurements?

$(f)$ how will the analytical results be calculated? 
When calcium is the element of interest or a very high precision is needed TIMS is the preferable quantification technique. Zinc, copper, iron and magnesium are easily measured with ICPMS with sufficient sensitivity for most applications. For selenium GCMS and negative TIMS are the only published techniques, but ICPMS may be developed as a useful alternative.

The faecal monitoring technique can be used for most minerals and trace elements of nutritional interest, and is especially valuable for elements with a high intestinal endogenous excretion such as zinc and copper. It is more difficult when a very low absorption can be expected, e.g. for iron. Simultaneous administration of oral and intravenous isotopes is a well established technique for the measurement of calcium absorption, and might also be feasible for absorption of magnesium, zinc and selenium. Tissue (red blood cell) retention has so far mainly been used for measurement of iron absorption but could with improved precision of the quantification techniques also be suitable for other elements with relatively high red blood cell concentrations, such as zinc and selenium. The plasma appearance technique is qualitative and best suited for comparative studies but has been shown to give quantitative figures for iron absorption when two isotopes were employed.

In conclusion, stable isotopes are useful tools for studies of absorption and metabolism of minerals and trace elements. They are especially valuable in studies of children, and pregnant and lactating women. Further methodological development is foreseen in this area to improve the precision of quantification techniques, to simplify and optimize the protocols for the studies, and to minimize the doses, thereby reducing the costs and improving the nutritional significance of the results.

\section{REFERENCES}

Abrams, S. A.. Esteban, N. V., Vieira, N. E., Sidbury, J. B., Specker, B. L. \& Yergey, A. L. (1992). Developmental changes in calcium kinetics in children assessed using stable isotopes. Journal of Bone and Mineral Research 7 , 287-293.

Arvidsson, B., Cederblad, А̊., Björn-Rasmussen, E. \& Sandström, B. (1978). A radionuclide technique for studies of zinc absorption in man. International Journal of Nuclear Medicine and Biology 5, $104-109$.

Aubert, J.-P., Bronner, F. \& Richelle, L. J. (1963). Quantitation of calcium metabolism. Theory. Journal of Clinical Investigation 42, 885-897.

August, D., Janghorbani, M. \& Young, V. R. (1989). Determination of zinc and copper absorption at three dietary $\mathrm{Zn}-\mathrm{Cu}$ ratios by using stable isotope methods in young adult and elderly subjects. American Journal of Clinical Nutrition 50, 1457-1463.

Barrett, J. F. R., Whittaker, P. G., Williams, J. G. \& Lind, T. (1992). Absorption of non-haem iron in normal women measured by the incorporation of two stable isotopes into erythrocytes. Clinical Science 83, $213-219$.

Birge, S. J., Peck, W. A., Berman, M. \& Whedon, G. D. (1969). Study of calcium absorption in man: a kinetic analysis and physiologic model. Journal of Clinical Investigation 48, 1705-1713.

Bronner, F. (1962). Experimental studies of calcium absorption in man. Bibliotheca ' Nutritio et Dieta' 3, $22-31$.

Christensen, M. J., Janghorbani, M., Steinke, F. H., Istfan, N. \& Young, V. R. (1983). Simultaneous determination of absorption of selenium from poultry meat and selenite in young men: application of a triple stable-isotope method. British Journal of Nutrition 50, 4350.

Cobelli, C., Toffolo, G., Bier, D. M. \& Nosadini, R. (1987). Models to interpret kinetic data in stable isotope tracer studies. American Journal of Physiology 253, E551-E564.

Davidsson, L., Cederblad, A., Lönnerdal, B. \& Sandström, B. (1989). Manganese retention in man: a method for estimating manganese absorption in man. American Journal of Clinical Nutrition 49.170-179.

DeGrazia, J. A., Ivanovich, P., Fellows, H. \& Rich, C. (1965). A double isotope method for measurement of intestinal absorption of calcium in man. Journal of Laboratory and Clinical Medicine 66, 822-829.

DeLaeter, J. R., Heumann, K. G. \& Rosman, K. J. R. (1991). Isotopic composition of the elements 1989. Journal of Physical and Chemical Reference Data 20, 1327-1337.

Eagles, J., Fairweather-Tait, S. J., Portwood, D. E., Self, R., Götz, A. \& Heumann, K. G. (1989). Comparison of fast atom bombardment mass spectrometry and thermal ionization quadrupole mass spectrometry for the measurement of zinc absorption in human nutrition studies. Analytical Chemistry 61, 1023-1025.

Egan, C. B., Smith, F. G., Houk, R. S. \& Serfass, R. E. (1991). Zinc absorption in women : comparison of intrinsic and extrinsic stable-isotope labels. American Journal of Clinical Nutrition 53, 547-553. 
Ehrenkranz, R. A., Gettner, P. A., Nelli, C. M., Sherwonit, E. A., Williams, P. A., Ting, B. T. G. \& Janghorbani, M. (1989). Zinc and copper nutritional studies in very low birth weight infants: comparison of stable isotopic extrinsic tag and chemical balance methods. Pediatric Research 26, 298-307.

Fairweather-Tait, S. J., Balmer, S. E., Scott, P. H. \& Minski, M. J. (1987a). Lactoferrin and iron absorption in newborn infants. Pediatric Research 22, 651-654.

Fairweather-Tait, S. J., Fox, T. E., Wharf, S. G., Eagles, J., Crews, H. M. \& Massey, R. (1991). Apparent zinc absorption by rats from food labelled intrinsically and extrinsically with ${ }^{67} \mathrm{Zn}$. British Journal of Nutrition 66 , $65-71$.

Fairweather-Tait, S. J., Fox, T. E., Wharf, S. G., Eagles, J. \& Kennedy, H. (1992). Zinc absorption in adult men from a chicken sandwich made with white or wholemeal bread, measured by a double-label stable-isotope technique. British Journal of Nutrition 67, 411-419.

Fairweather-Tait, S. J, Jackson, M. J., Fox, T. E., Wharf, S. G., Eagles, J. \& Croghan, P. C. (1993). The measurement of exchangeable pools of zinc using the stable isotope ${ }^{70} \mathrm{Zn}$. British Journal of Nutrition 70 , 221-234.

Fairweather-Tait, S. J., Johnson, A., Eagles, J., Ganatra, S., Kennedy, H. \& Gurr, M. I. (1989a). Studies on calcium absorption from milk using a double-label stable isotope technique. British Journal of Nutrition 62 , 379-388.

Fairweather-Tait, S. J., Minski, M. J. \& Richardson, D. P. (1983). Iron absorption from a malted cocoa drink fortified with ferric orthophosphate using the stable isotope ${ }^{58} \mathrm{Fe}$ as an extrinsic label. British Journal of Nutrition 50, 51-60.

Fairweather-Tait, S. J., Minski, M. J. \& Singh, J. (1987b). Nonradioisotopic method for measuring iron absorption from a Gambian meal. American Journal of Clinical Nutrition 46, 844-848.

Fairweather-Tait, S. J., Portwood, D. E., Symss, L. L., Eagles, J. \& Minski, M. J. (1989b). Iron and zinc absorption in human subjects from a mixed meal of extruded and nonextruded wheat bran and flour. American Journal of Clinical Nutrition 49, 151-155.

Fomon. S. J., Janghorbani, M., Ting, B. T. G., Ziegler, E. E., Rogers, R. R., Nelson, S. E., Ostedgaard, L. S. \& Edwards, B. B. (1988). Erythrocyte incorporation of ingested 58-iron by infants. Pediatric Research $24,20-24$.

Fomon, S. J., Ziegler, E. E.. Rogers, R. R., Nelson, S. E., Edwards, B. B., Guy, D. G., Erve, J. C. \& Janghorbani, M. (1989). Iron absorption from infant foods. Pediatric Research 26, 250-254.

Friel, J. K., Naake, V. L., Miller, L. V., Fennessey, P. V. \& Hambidge, K. M. (1992). The analysis of stable isotopes in urine to determine the fractional absorption of zinc. American Journal of Clinical Nutrition $\mathbf{5 5}$, 473-477.

Garner, R. J., Jones, H. G. \& Sansom, B. F. (1960). Fission products and the dairy cow. 2. Some aspects of the metabolism of the alkaline-earth elements calcium, strontium and barium. Biochemical Journal 76, 572-579.

Gibaldi, M. \& Perrier, D. (1982). Pharmacokinetics, 2nd edn (Drugs and the Pharmaceutical Sciences Vol. 15). New York: Marcel Dekker.

Gibson, R. S., Gibson, I. L., Webber, C. E. \& Atkinson, S. A. (1988). An improved multi-element measurement of mineral absorption in the piglet utilizing the fecal monitoring technique. Biological Trace Element Research 17, 139-149.

Hallberg, L. (1981). Bioavailability of dietary iron in man. Annual Review of Nutrition 1, $123-147$.

Heumann, K. G. \& Rädlein, N. (1989). Negative thermal ionization mass spectrometry of selenium. 3. Selenium trace determination in food samples. Fresenius' Zeitschrift für Analytische Chemie 335, 751-754.

Hillman, L. S., Tack, E.. Covell, D. G., Vieira, N. E. \& Yergey, A. L. (1988). Measurement of true calcium absorption in premature infants using intravenous ${ }^{46} \mathrm{Ca}$ and oral ${ }^{44} \mathrm{Ca}$. Pediatric Research $23,589--594$.

Hosain, F., Marsaglia, G. \& Finch, C. A. (1967). Blood ferrokinetics in normal man. Journal of Clinical Investigation 46, 1-9.

Istfan. N. W., Janghorbani, M. \& Young, V. R. (1983). Absorption of stable ${ }^{70} \mathrm{Zn}$ in healthy young men in relation to zinc intake. American Journal of Clinical Nutrition 38, $187-194$.

Jackson, M. J., Giugliano, R.. Giugliano, L. G., Oliveira, E. F., Shrimpton, R. \& Swainbank, I. G. (1988). Stable isotope metabolic studies of zinc nutrition in slum-dwelling lactating women in the Amazon valley. British Journal of Nutrition 59, 193-203.

Jackson, M. J., Jones, D. A., Edwards, R. H. T., Swainbank, I. G. \& Coleman. M. L. (1984). Zinc homeostasis in man: studies using a new stable isotope-dilution technique. British Journal of Nutrition 51, 199-208.

Janghorbani, M., Christensen, M. J., Nahapetian, A. \& Young, V. R. (1982a). Selenium metabolism in healthy adults: quantitative aspects using the stable isotope ${ }^{74} \mathrm{SeO}_{3}^{2-}$. American Journal of Clinical Nutrition 35, 647-654.

Janghorbani, M., Istfan, N. W., Pagounes, J. O., Steinke, F. H. \& Young, V. R. (1982b). Absorption of dietary zinc in man: comparison of intrinsic and extrinsic labels using a triple stable isotope method. American Journal of Clinical Nutrition 36, 537-545.

Janghorbani, M., Martin, R. F., Kasper, L. J., Sun, X. F. \& Young, V. R. (1990). The selenite-exchangeable metabolic pool in humans: a new concept for the assessment of selenium status. American Journal of Clinical Nutrition 51, 670-677.

Janghorbani, M., Ting, B. T. \& Fomon, S. J. (1986). Erythrocyte incorporation of ingested stable isotope of iron $\left({ }^{58} \mathrm{Fe}\right)$. American Journal of Hematology 21, 277-288.

Janghorbani, M., Ting, B. T. G., Istfan, N. W. \& Young, V. R. (1981a). Measurements of ${ }^{68} \mathrm{Zn}$ and ${ }^{70} \mathrm{Zn}$ in human blood in reference to the study of zinc metabolism. American Journal of Clinical Nutrition 34, 581-591. 
Janghorbani, M., Ting, B. T. G. \& Young, V. R. (1980). Accurate analysis of stable isotopes ${ }^{68} \mathrm{Zn}$, ${ }^{70} \mathrm{Zn}$, and ${ }^{58} \mathrm{Fe}$ in human feces with neutron activation analysis. Clinica Chimica Acta 108, 9-24.

Janghorbani, M., Ting, B. T. G., Young, V. R. \& Steinke, F. H. (1981b). Intrinsic labelling of chicken meat with stable isotopes of zinc, for intended use in human feeding studies: feasibility and design considerations. British Journal of Nutrition 46, 395-402.

Janghorbani, M., Weaver, C. M., Ting, B. T. G. \& Young, V. R. (1983). Labeling of soybeans with the stable isotope ${ }^{70} \mathrm{Zn}$ for use in human metabolic studies. Journal of Nutrition 113, 973-978.

Janghorbani. M. \& Young, V. R. (1982). Stable isotopes in studies of dietary mineral bioavailability in humans, with special reference to zinc. In Clinical, Biochemical, and Nutritional Aspects of Trace Elements (Current Topics in Nutrition and Disease Vol. 6), pp. 447-468 [A. Prasad, editor]. New York: Alan R. Liss.

Janghorbani, M., Young, V. R., Gramlich, J. W. \& Machlan, L. A. (1981 c). Comparative measurements of zinc70 enrichment in human plasma samples with neutron activation and mass spectrometry. Clinica Chimica Acta 114,163171 .

Johnson, P. E. (1982). A mass spectrometric method for use of sta' Jle isotopes as tracers in studies of iron, zinc, and copper absorption in human subjects. Journal of Nutrition 112, 1414-1424.

Johnson, P. E., Stuart, M. A., Hunt, J. R., Mullen, L. \& Starks, T. L. (1988). ${ }^{65}$ Copper absorption by women fed intrinsically and extrinsically labeled goose meat, goose liver, peanut butter and sunflower butter. Journal of Nutrition 118, 15221528.

Kastenmayer, P., Davidsson, L., Galan, P., Cherouvrier, F., Hercberg, S. \& Hurrell, R. F. (1993). Iron absorption in infants measured by a double stable isotope technique. British Journal of Nutrition. In press.

King, J. C., Raynolds, W. L. \& Margen, S. (1978). Absorption of stable isotopes of iron, copper, and zinc during oral contraceptive use. American Journal of Clinical Nutrition 31, 1198- 1203.

Lehmann, W. D. \& Kessler, M. (1982). Calcium absorption studies in man by stable isotope dilution and field desorption mass spectrometry. In Stable Isotopes (Analytical Chemistry Symposium Series Vol. 11), pp. 649-654 [H.-L. Schmidt, H. Forstel and K. Heinzinger, editors]. Amsterdam: Elsevier.

Liu, Y.-M., Neal, P., Ernst, J., Weaver, C., Rickard, K., Smith, D. L. \& Lemons, J. (1989). Absorption of calcium and magnesium from fortified human milk by very low birth weight infants. Pediatric Research 25, 496-502.

Lowe, N. M., Green, A., Rhodes, J. M., Lombard, M., Jalan, R. \& Jackson, M. J. (1993). Studies of human zinc kinetics using the stable isotope ${ }^{70}$ Zinc. Clinical Science 84, 113. 117.

Mangels, A. R., Moser-Veillon, P. B., Patterson, K. Y. \& Veillon, C. (1990). Selenium utilization during human lactation by use of stable-isotope tracers. American Journal of Clinical Nutrition 52, 621-627.

Martin, B. R., Weaver, C. M. \& Smith, D. L. (1989). Calcium absorption from milk vs. calcium carbonate in college age women using stable isotopes. FASEB Journal 3, A771 (abstr. 3160).

Martin, R. F., Janghorbani, M. \& Young, V. R. (1988). Kinetics of a single administration of ${ }^{74}$ Se-selenite by oral and intravenous routes in adult humans. Journal of Parenteral and Enteral Nutrition 12, 351-355.

Mason, P. M., Judd, P. A., Fairweather-Tait, S. J., Eagles, J. \& Minski, M. J. (1990). The effect of moderately increased intakes of complex carbohydrates (cereals, vegetables and fruit) for 12 weeks on iron and zinc metabolism. British Journal of Nutrition 63, 597611.

Miller, J. Z., Smith, D. L., Flora, L., Peacock, M. \& Johnston, C. C. (1989). Calcium absorption in children estimated from single and double stable calcium isotope techniques. Clinica Chimica Acta 183, 107113.

Miller, J. Z. Smith, D. L., Flora, L., Slemenda, C., Jiang, X. \& Johnston. C. C. (1988). Calcium absorption from calcium carbonate and a new form of calcium (CCM) in healthy male and female adolescents. American Journal of Clinical Nutrition 48, 12911294

Molokhia, M., Sturniolo, G., Shields, R. \& Turnberg, L. A. (1980). A simple method for measuring zinc absorption in man using a short-lived isotope $\left({ }^{69 \mathrm{~m}} \mathrm{Zn}\right)$. American Journal of Clinical Nutrition 33, 881-886.

Moser-Veillon, P. B.. Vieira, N. E., Yergey, A. L., Nagey, D. A., Patterson. K. Y. \& Veillon, C. (1989). Fractional absorption and urinary excretion of calcium (Ca) stable isotopes in lactating and nonlactating women. $F A S E B$ Journal 3, A645 (Abstr. 2433).

Neer, R., Tully, G., Schatz, P. \& Hnatowich, D. J. (1978). Use of stable ${ }^{48} \mathrm{Ca}$ in the clinical measurement of intestinal calcium absorption. Calcified Tissue Research 26, 5-11.

Patterson, B. H., Levander, O. A., Helzlsouer, K., McAdam, P. A., Lewis, S. A., Taylor, P. R., Veillon, C. \& Zech, L. A. (1989). Human selenite metabolism: a kinetic model. American Journal of Physiology 257, R556-R567.

Price, R. I., Kent, G. N., Rosman, K. J. B., Gutteridge, D. H., Reeve, J., Allen, J. P., Stuckey, B. G. A., Smith, M., Guelfi, G., Hickling, C. J. \& Blakeman, S. L. (1990). Kinetics of intestinal calcium absorption in humans measured using stable isotopes and high-precision thermal ionization mass spectrometry. Biomedical and Environmental Mass Spectrometry 19, 353-359.

Rabinowitz, M. B., Wetherill, G. W. \& Kopple, J. D. (1973). Lead metabolism in the normal human: stable isotope studies. Science 182, 725-727.

Reamer, D. C. \& Veillon, C. (1981). Determination of selenium in biological materials by stable isotope dilution gas chromatography-mass spectrometry. Analytical Chemistry 53, 2166-2169.

Roth, P. \& Werner, E. (1985). Interrelations of radiocalcium absorption tests and their clinical relevance. Mineral and Electrolyte Metabolism 11, 351-357.

Schwartz. R. \& Giesecke, C. C. (1979). Mass spectrometry of a volatile $\mathrm{Mg}$ chelate in the measurement of stable ${ }^{26} \mathrm{Mg}$ when used as a tracer. Clinica Chimica Acta 97, 1-8. 
Schwartz, R., Spencer, H. \& Welsh, J. J. (1984). Magnesium absorption in human subjects from leafy vegetables, intrinsically labeled with stable ${ }^{26} \mathrm{Mg}$. American Journal of Clinical Nutrition 39, 571-576.

Schwartz, R., Spencer, H. \& Wentworth, R. A. (1978). Measurement of magnesium absorption in man using stable ${ }^{26} \mathrm{Mg}$ as a tracer. Clinica Chimica Acta 87, 265273.

Self, R., Eagles, J., Fairweather-Tait, S. J. \& Portwood, D. E. (1987). Fast atom bombardment mass spectrometry (FABMS) of mineral nutrients in human nutrition studies. Analytical Proceedings 24, 366-367.

Serfass, R. E., Ziegler, E. E., Edwards, B. B. \& Houk, R. S. (1989). Intrinsic and extrinsic stable isotopic zinc absorption by infants from formulas. Journal of Nutrition 119, 16611669.

Shipley, R. A. \& Clark, R. E. (1972). Tracer Methods for In Vivo Kinetics: theory and applications. New York: Academic Press.

Sirichakwal, P. P., Young, V. R. \& Janghorbani, M. (1985). Absorption and retention of selenium from intrinsically labeled egg and selenite as determined by stable isotope studies in humans. American Journal of Clinical Nutrition 41, 264-269.

Smith, D. L., Atkin, C. \& Westenfelder, C. (1985). Stable isotopes of calcium as tracers: methodology. Clinica Chimica Acta 146, $97 \cdot 101$.

Solomons, N. W., Janghorbani, M., Ting, B. T. G., Steinke, F. H., Christensen, M., Bijlani, R., Istfan, N. \& Young, V. R. (1982). Bioavailability of zinc from a diet based on isolated soy protein: application in young men of the stable isotope tracer, ${ }^{70} \mathrm{Zn}$. Journal of Nutrition $112,1809-1821$.

Swanson, C. A., Turnlund, J. R. \& King, J. C. (1983). Effect of dietary zinc sources and pregnancy on zinc utilization in adult women fed controlled diets. Journal of Nutrition 113, 2557-2567.

Taylor. C. M., Bacon, J. R., Aggett, P. J. \& Bremner, I. (1991). Homeostatic regulation of zinc absorption and endogenous losses in zinc-deprived men. American Journal of Clinical Nutrition 53, 755763.

Turnlund, J. R. (1989). The use of stable isotopes in mineral nutrition research. Journal of Nutrition $119,714$.

Turnlund, J. R. (1991). Bioavailability of dietary minerals to humans: the stable isotope approach. CRC Critical Reviews in Food Science and Nutrition 30, 387-396.

Turnlund, J. R., Durkin, N., Costa. F. \& Margen, S. (1986). Stable isotope studies of zinc absorption and retention in young and elderly men. Journal of Nutrition 116. 1239-1247.

Turnlund, J. R., Keyes, W. R., Hudson, C. A., Betschart, A. A., Kretsch, M. J. \& Sauberlich, H. E. (1991). A stable-isotope study of zinc, copper, and iron absorption and retention by young women fed vitamin B-6deficient diets. American Journal of Clinical Nutrition 54, 10591064.

Turnlund, J. R., King, J. C., Gong, B., Keyes, W. R. \& Michel, M. C. (1985). A stable isotope study of copper absorption in young men: effect of phytate and $\alpha$-cellulose. American Journal of Clinical Nutrition 42, $18-23$.

Turnlund, J. R., King, J. C., Keyes, W. R., Gong, B. \& Michel, M. C. (1984). A stable isotope study of zinc absorption in young men: effects of phytate and $x$-cellulose. American Journal of Clinical Nutrition $\mathbf{4 0}$, $1071 \cdot 1077$.

Turnlund, J. R., Michel, M. C., Keyes, W. R., King, J. C. \& Margen, S. (1982 b). Use of enriched stable isotopes to determine zinc and iron absorption in elderly men. American Journal of Clinical Nutrition 35, $1033-1040$.

Turnlund, J. R., Michel, M. C., Keyes, W. R., Schutı, Y. \& Margen, S. (1982a). Copper absorption in elderly men determined by using stable ${ }^{65} \mathrm{Cu}$. American Journal of Clinical Nutrition 36, 587-591.

Turnlund, J. R., Wada, L., King, J. C., Keyes, W. R. \& Acord, L. L. (1988). Copper absorption in young men fed adequate and low zinc diets. Biological Trace Element Research 17, 31-41.

Wada, L., Turnlund, J. R. \& King, J. C. (1985). Zinc utilization in young men fed adequate and low zinc intakes. Journal of Nutrition 115, 1345 - 1354.

Wastney, M. E., Gökmen, I. G., Aamodt, R. L., Rumble, W. F., Gordon, G. E. \& Henkin. R. I. (1991). Kinetic analysis of zinc metabolism in humans after simultaneous administration of ${ }^{65} \mathrm{Zn}$ and ${ }^{70} \mathrm{Zn}$. American Journal of Physiology 260, R134-R141

Wastney, M. E. \& Henkin, R. I. (1989). Calculation of zinc absorption in humans using tracers by fecal monitoring and a compartmental approach. Journal of Nutrition 119, 1438-1443.

Weaver, C. M. (1985). Intrinsic mineral labeling of edible plants: methods and uses. CRC Critical Reviews in Food Science and Nutrition 23, 75-101.

Weaver, C. M. (1988). Isotopic tracer methodology: potential in mineral nutrition. In Trace Minerals in Food (Food Science \& Technology Vol. 28), pp. 429454 [K. T. Smith, editor]. New York: Marcel Dekker.

Weaver, C. M., Heaney, R. P., Martin, B. R. \& Fitzsimmons, M. L. (1992). Extrinsic vs intrinsic labeling of the calcium in whole-wheat flour. American Journal of Clinical Nutrition 55, 452454.

Wharf, S. G., Fox, T. E., Eagles, J. \& Fairweather-Tait, S. J. (1993). A stable isotope method for determining bioavailability from infant weaning foods. In Proceedings of Bioavailability' '93, pp. 254-257 [U. Schlemmer, editor]. Karlsruhe: Bundesforschungsanstalt für Ernährung.

Whittaker, P. G., Lind, T. \& Williams, J. G. (1991). Iron absorption during normal human pregnancy: a study using stable isotopes. British Journal of Nutrition 65, 457-463.

Whittaker, P. G., Lind, T., Williams, J. G. \& Gray, A. L. (1989). Inductively coupled plasma mass spectrometric determination of the absorption of iron in normal women. Analyst 114, 675678

Yergey, A. L., Abrams, S. A., Vieira, N. E., Eastell, R., Hillman, L. S. \& Covell, D. G. (1990). Recent studies of human calcium metabolism using stable isotopic tracers. Canadian Journal of Physiology and Pharmacology 68, 973-976. 
Yergey, A. L., Vieira. N. E. \& Covell, D. G. (1987). Direct measurement of dietary fractional absorption using calcium isotopic tracers. Biomedical and Environmental Mass Spectrometry 14, 603-607.

Yergey, A. L., Vieira, N. E. \& Hansen, J. W. (1980). Isotope ratio measurements of urinary calcium with a thermal ionization probe in a quadrupole mass spectrometer. Analytical Chemistry 52, 1811-1814.

Ziegler, E. E., Serfass, R. E., Nelson, S. E., Figueroa-Colón, R., Edwards, B. B., Houk, R. S. \& Thompson, J. J. (1989). Effect of low zinc intake on absorption and excretion of zinc by infants studied with ${ }^{70} \mathrm{Zn}$ as extrinsic tag. Journal of Nutrition 119, 1647-1653. 